\title{
Linkage and association of the CA repeat polymorphism of the ILG gene, obesity-related phenotypes, and bone mineral density (BMD) in two independent Caucasian populations
}

Received: 8 May 2003/ Accepted: 23 June 2003 / Published online: 26 July 2003

(C) The Japan Society of Human Genetics and Springer-Verlag 2003

\begin{abstract}
Genetic factors play an important role in osteoporosis and obesity, two serious public health problems in the world. We investigated the relationships between obesity-related phenotypes, bone mineral density (BMD) and the CA repeat polymorphism of the IL6 gene in two large independent samples using the quantitative transmission disequilibrium test (QTDT). The first sample consisted of 1,816 individuals from 79 multigenerational pedigrees. Each pedigree was identified through a proband with BMD Z-scores $\leq-1.28$ at the hip or spine. The second sample was a randomly ascertained set of 636 individuals from 157 nuclear families. Ten alleles containing 9-18 CA repeats were identified in our Caucasian populations. For body mass index (BMI), fat mass and percentage fat mass (PFM), highly significant $(P<0.01)$ or significant $(P<0.05)$ results were found for linkage in our sample of nuclear families and for association in the multigenerational pedigrees. We also observed weak evidence for linkage $(P=0.069)$ with spine BMD and for association with hip BMD in the sample of multigenerational pedigrees. Our results suggest that genetic variation in or near the IL6
\end{abstract}

Q.-Y. Huang $\cdot$ H. Shen $\cdot$ H.-Y. Deng $\cdot$ T. Conway

K. M. Davies - R. R. Recker · H.-W. Deng $(\bowtie)$

Osteoporosis Research Center, Creighton University, 601 N. 30th St., Suite 6787, Omaha, NE 68131, USA

E-mail: deng@creighton.edu

Tel.: + 1-402-2805911

Fax: + 1-402-2805034

Q.-Y. Huang $\cdot$ H. Shen $\cdot$ H.-W. Deng

Department of Biomedical Sciences, Creighton University, 601 N. 30th St., Suite 6787, Omaha, NE 68131, USA

Q.-Y. Huang · H.-W. Deng

Laboratory of Molecular and Statistical Genetics, College of Life Sciences, Hunan Normal University, 410081, ChangSha, Hunan, P.R. China

J.-L. Li

Center for Medical Informatics, School of Medicine, Yale University, 333 Cedar Street, P.O. Box 208009, New Haven, CT 06520-8009, USA locus may be involved in the etiology of obesity and osteoporosis.

Keywords Osteoporosis - Obesity IL6 gene · Association $\cdot$ Linkage $\cdot$ Transmission disequilibrium test

\section{Introduction}

Osteoporosis is a major public health problem, particularly for women, who have a $40-50 \%$ lifetime risk of osteoporotic fractures (Melton et al. 1992). Low bone mineral density (BMD) is an important risk factor for osteoporotic fractures, and osteoporosis is mainly characterized by low BMD. It is known that BMD variation is determined largely by genetic factors, with heritability estimates ranging from 0.5 to 0.9 (Dequeker et al. 1987; Pocock et al. 1987; Slemeda et al. 1991; Gueguen et al. 1995; Nguyen et al. 1998; Deng et al. 1999, 2000). Interleukin-6 (IL6) is a pleiotropic cytokine that has important effects on osteoclast differentiation and function (Roodman 1992; Jilka et al. 1992). IL6 maps to chromosome 7p21. IL6 mRNA expression in bone is enhanced in $95 \%$ of patients with osteoporotic vertebral fractures compared with $50 \%$ of postmenopausal controls (Ralston 1994). Some have reported an association between polymorphisms of the IL6 gene and BMD (Murray et al. 1997; Tsukamoto et al. 1999; Ferrari et al. 2001; Ota et al. 2001). However, others have reported negative results (Takacs et al. 2000; Weerakulwattana et al. 2001). In addition, the IL6 gene locus showed weak linkage with BMD of the lumbar spine but not of the femoral neck in Caucasian families in UK (Duncan et al. 1999). Recently, we performed a whole genome screen in a sample of 53 pedigrees with 630 Caucasian subjects. Chromosome $7 \mathrm{p} 22$ showed some evidence of linkage to spine BMD with a multi-point LOD $=1.93$ (Deng et al. 2002b). 
Obesity, usually defined as a body mass index (BMI) greater than $30 \mathrm{~kg} / \mathrm{m}^{2}$, is a growing public health problem (Kopelman 2000). Numerous studies have indicated that obesity-related phenotypes, including BMI, are under genetic control with heritability estimates ranging from 0.5 to 0.9 (Borecki et al. 1998; Nguyen et al. 1998; Rice et al. 1999; Deng et al. 2001). Chromosome $7 \mathrm{p} 15-22$, where the IL6 gene is located, showed suggestive evidence of linkage to BMI in an Asian population $(\mathrm{LOD}=2.66$, at marker $\mathrm{D} 7 \mathrm{~S} 3051)$ (Wu et al. 2002), and 7p22 showed marginal evidence for linkage to BMI in a French population $(\mathrm{MLS}=1.27$, at marker D7S517) (Hager et al. 1998). Recently, we performed another whole genome screen in the sample of 53 pedigrees with 630 Caucasian subjects. Chromosome 7 p22 showed some evidence of linkage to lean mass with a multi-point $\mathrm{LOD}=1.52$ (Deng et al. 2002a). Circulating IL6 levels have been reported to be elevated in obese people, and correlated with BMI (Vgontzas et al. 1997). IL6-deficient mice develop mature-onset obesity (Wallenius et al. 2002). However, to our knowledge, few studies have examined the relationship between polymorphisms of the IL6 gene and obesity-related phenotypes (Rankinen et al. 2002). Recently, Berthier et al. (2003) observed a significant effect of the IL6 variant on obesity. The $-174 \mathrm{G}$ allele was more commonly observed among lean subjects (low BMI and low waist circumference), with carriers of the $-174 \mathrm{C}$ allele being characterized by a larger waistline.

The aim of the present study was to test for linkage and association between BMD, obesity-related phenotypes, and the CA repeat polymorphism of the IL6 gene in two large independent samples with different study designs using the quantitative transmission disequilibrium test (QTDT) (Rabinowitz 1997; Fulker et al. 1999; Abecasis et al. 2000a, 2000b).

\section{Subjects and methods}

\section{Subjects}

The study subjects came from an expanding database being created for a whole genome linkage study aimed at searching for genes underlying osteoporosis and obesity that is underway in the Osteoporosis Research Center of Creighton University. All the study subjects were Caucasians of European origin. Only healthy people were included in the analyses. The exclusion criteria are detailed in Deng et al. (2002a). The study included two groups of subjects. The first group of subjects was composed of 1,816 individuals from 79 multigenerational pedigrees. Each pedigree was identified through a proband with BMD Z-scores $\leq-1.28$ at the hip or spine so that the probands were selected from the bottom $10 \%$ of the population BMD variation with the purpose of achieving higher statistical power than with random sampling. In total, there were 3,393 sibling pairs, 316 grandparent-grandchild pairs, and 10,060 first-cousin pairs. The second group was a randomly ascertained set of 636 individuals from 157 nuclear families, in which 62 families have one child, 43 families two children, 34 families three children, and the remainder four or more children. The study was approved by the Creighton University Institutional Review Board. All subjects participating in this study signed informed-consent documents before entering the project.

\section{Genotyping}

DNA was extracted from whole blood using a commercial isolation kit (Gentra Systems, Minneapolis, Minn., USA) following the procedures detailed in the kit. The dinucleotide (CA) repeat polymorphism of the IL6 gene locus was genotyped. PCR primers were IL6-CAF, 5'-TTCTACATGACAGCAGAACAC-3', and IL6CAR, 5'-TCTGTGGGAAAGTATATGTGC-3') (Ota et al. 1999). The forward primer was labeled at the $5^{\prime}$ terminus with a fluorescent tag. PCRs were performed in a final volume of $8 \mu \mathrm{l}$, containing $1 \times$ PCR buffer, $1.5 \mathrm{mM} \mathrm{MgCl} 2,200 \mu \mathrm{M}$ each dNTP, $0.06 \mathrm{U}$ Taq Polymerase (Applied Biosystems, Foster City, CA, USA), $0.4 \mu \mathrm{M}$ each of the two primers, $\sim 50 \mathrm{ng}$ of genomic DNA. Amplification conditions were ten cycles at $95^{\circ} \mathrm{C}$ for $15 \mathrm{~s}, 55^{\circ} \mathrm{C}$ for $15 \mathrm{~s}$, and $72^{\circ} \mathrm{C}$ for $30 \mathrm{~s}$, followed by 20 cycles of $89^{\circ} \mathrm{C}$ for $15 \mathrm{~s}, 55^{\circ} \mathrm{C}$ for $15 \mathrm{~s}$, and $72{ }^{\circ} \mathrm{C}$ for $30 \mathrm{~s}$. Prior to the first cycle, initial denaturation was performed at $94{ }^{\circ} \mathrm{C}$ for $10 \mathrm{~min}$ and the last cycle was followed by an extension step of $10 \mathrm{~min}$ at $72{ }^{\circ} \mathrm{C}$. PCR products were separated by electrophoresis on an ABI 3700 DNA Analyzer (Applied Biosystems, Foster City, CA, USA). Gels were analyzed using the GeneScan and Genotyper softwares (Applied Biosystems, Foster City, CA, USA). The program PedCheck (O'Connell and Weeks, 1998; available at http://watson.hgen.pitt.edu/register/soft_doc.html) was employed for verifying Mendelian inheritance of all the marker alleles and for checking the relationships of family members within pedigrees.

\section{Phenotyping}

BMD at the spine (L1-4) and hip (femoral neck, trochanter and intertrochanter), fat mass, and lean mass were measured by a Hologic 1000, 2000 +, or 4500 scanner (Hologic, Waltham, Mass.). Hip and spine were chosen because they are the most common osteoporotic fracture sites. The measurement precision as reflected by coefficients of variation for spine BMD, hip BMD, fat mass, and lean mass were $0.7 \%, 1.0 \%, 1.2 \%$, and $0.7 \%$, respectively. Data obtained from different machines are transformed to a compatible measurement by an algorithm as in our previous studies (Recker et al. 2000) and members of the same pedigree usually are measured on the same type of machine. Weight and height were measured at the same visit when the BMD measurements were taken. BMI and percentage fat mass (PFM) were calculated.

\section{Statistical analyses}

A commonly used test for linkage and association in family data is the transmission disequilibrium test (TDT) for qualitative traits. This test has been extended to quantitative traits (Abecasis et al. 2000a), multi-allelic markers, and extended pedigrees (Abecasis et al. 2000b). We performed tests for population stratification, association (multi-allelic association test, association test within family and total association test), and linkage between the CA repeat polymorphism of the IL6 gene, with BMDs at the spine and hip, obesity-related phenotypes including BMI, fat mass, and PFM using the quantitative transmission disequilibrium test (QTDT) program (Rabinowitz 1997; Fulker et al. 1999; Abecasis et al. 2000a, 2000b; available at http://www.well.ox.ac.uk/asthma/ QTDT). The test of population stratification evaluates if the between-family component is equal to within-family component. Multi-allelic association included all alleles in one test as a categorical variable with allele frequencies of $<5 \%$ being pooled. Total association tests include three categorical variables, representing homozygoous alleles, heterozygous alleles, and the remaining pooled genotypes, respectively. Total association evaluates the total evidence for association at population level and is not a TDT. It can produce misleading results in the presence of population stratification. Association test within family is a TDT and is not subject to population stratification. Linkage analysis in the QTDT is based on the identity-by-descent (IBD) relationship of genotypes among 
sib pairs. These tests were all developed under a variance component framework. The QTDT program generates $P$ values for various tests via asymptotic $\chi^{2}$ distributions. In all the statistical analysis, age and sex have been used as covariates (if having significant effects in our sample) to adjust for BMI, fat mass, and PFM, whereas age, sex, height, and weight were used as covariates to adjust for raw BMD values (not the Z-scores). These factors generally affect BMD and obesity-related phenotype variation significantly (Deng et al. 2001). Generally, adjustment for significant covariates in genetic analyses can increase the genetic signal to noise ratio by decreasing the proportion of the residual phenotypic variation attributable to random environmental factors (Deng et al. 2000). This can improve statistical power in our linkage and/or association analyses.

\section{Results}

The basic characteristic of the study subjects stratified by age and sex are summarized in table A and table B of the Appendix.

Allele frequency distribution of the CA repeat polymorphism in our samples

Allele frequency of the CA repeat polymorphism at the IL6 gene locus in multigenerational pedigrees and nuclear families are presented in Table 1. Ten different alleles were found in our Caucasians populations. Their sizes ranged from 116 to $134 \mathrm{bp}$, which differ from the Japanese in a previous study (Ota et al. 1999), where six alleles ranging in size from 124 to 134 bp were observed.

The CA repeat polymorphism of the IL 6 gene and obesity-related phenotypes

For the sample of the nuclear families, tests for linkage yielded significant results for BMI, fat mass $(P<0.01)$, and PFM $(P<0.05)$ (see Table 2). Although the 17-repeat allele $(132 \mathrm{bp})$ was consistently associated with higher BMI $(P<0.05)$, higher fat mass $(P<0.05)$, and higher PFM $(P<0.1)$ in total association test, population stratification and association within family at the allele were not tested because of low allele frequency.
Furthermore, multi-allelic association tests were not significant.

For the sample of the multigenerational pedigrees, tests for linkage are not significant for BMI, fat mass and PFM (Table 2). When testing for association within family, significant results were detected for fat mass and PFM at the 15 -repeat allele $(128 \mathrm{bp})(P<0.01)$ and 11 -repeat allele $(120 \mathrm{bp})(P<0.05)$. Notably, because population stratification for fat mass and PFM was detected for the 11-repeat and 15-repeat alleles, total association tests for these two alleles were not significant.

The CA repeat polymorphism of the $I L 6$ gene and BMD

For the sample of the multigenerational pedigrees, the CA repeat polymorphism of the IL6 gene was weakly linked to spine $\operatorname{BMD}(P=0.069)$ (see Table 3$)$. Also, a weak association was found between the hip BMD and 11-repeat $(P=0.06)$ and 15 -repeat $(P=0.088)$ alleles in the association tests within family. For the sample of nuclear families, no significant results were observed for linkage, multi-allelic association, and association within family. Although total association tests for spine and hip BMD at the 16-repeat allele (130) were significant, population stratification and association within family at the allele were not tested because of low allele frequency. Furthermore, multi-allelic association tests were not significant.

\section{Discussion}

Since Morrison et al. (1994) reported an association between the vitamin $\mathrm{D}$ receptor gene and spine and hip BMD, numerous association studies have been described, with conflicting results (Audí et al. 1999; Rizzoli et al. 2001; Ralston 2002; Huang et al. 2003). Most of these studies used the association study approach in random population samples. The association study approach may yield spurious positive or spurious negative associations between complex traits and candidate genes because of population admixture and stratification (Deng 2001). QTDT can largely eliminate effects of

Table 1 Allele frequency distribution of the CA repeat polymorphism at the $I L 6$ gene locus in Caucasian and Japanese populations

\begin{tabular}{|c|c|c|c|c|}
\hline \multirow[t]{2}{*}{ IL6 alleles (bp) } & \multirow[t]{2}{*}{ CA repeat no. } & \multicolumn{3}{|l|}{ Frequency $(\%)$} \\
\hline & & Multigenerational pedigrees & Nuclear families & Japanese population (Ota et al. 1999) \\
\hline 116 & 9 & 0.41 & 0.31 & - \\
\hline 118 & 10 & 8.76 & 7.57 & - \\
\hline 120 & 11 & 32.44 & 32.35 & - \\
\hline 122 & 12 & 23.07 & 25.28 & - \\
\hline 124 & 13 & 0.75 & 0.78 & 15 \\
\hline 126 & 14 & 30.58 & 30.28 & 62 \\
\hline 128 & 15 & 1.66 & 1.4 & 3 \\
\hline 130 & 16 & 1.83 & 1.25 & 7 \\
\hline 132 & 17 & 0.33 & 0.78 & 8 \\
\hline 134 & 18 & 0.17 & - & 5 \\
\hline
\end{tabular}


Table $2 \chi^{2}$ statistics obtained from QTDT analysis of the IL6 gene and obesity-related phenotypes. A blank entry indicates lack of the allele in the sample; a dash indicates not tested because the frequency of the allele is less than $5 \%$; asterisks indicate significant values
*Significant at the level of 0.10 ** Significant at the level of 0.05 $* * *$ Significant at the level of 0.01

\begin{tabular}{|c|c|c|c|c|c|c|}
\hline \multirow[t]{2}{*}{ IL6 alleles (bp) } & \multicolumn{3}{|c|}{ Multigenerational pedigrees } & \multicolumn{3}{|c|}{ Nuclear families } \\
\hline & BMI & Fat mass & PFM & BMI & Fat mass & PFM \\
\hline \multicolumn{7}{|c|}{ Tests of population stratification } \\
\hline 116 & 0.17 & 0.00 & 0.09 & - & - & - \\
\hline 118 & 0.03 & 0.34 & 0.00 & 0.35 & 0.05 & 0.02 \\
\hline 120 & 1.64 & $4.07 * *$ & $3.10^{*}$ & 0.02 & 0.00 & 0.41 \\
\hline 122 & $2.83^{*}$ & $5.39 * *$ & $3.38^{*}$ & 0.59 & 1.01 & 0.81 \\
\hline 124 & - & - & - & - & - & - \\
\hline 126 & 0.27 & 1.27 & 0.82 & 0.95 & 1.62 & 0.32 \\
\hline 128 & 2.63 & $3.27 *$ & $3.82 *$ & - & - & - \\
\hline 130 & 1.25 & 0.06 & 0.07 & - & - & - \\
\hline 132 & - & - & - & - & - & - \\
\hline 134 & - & - & - & & & \\
\hline \multicolumn{7}{|c|}{ Total association tests } \\
\hline 116 & 0.19 & 0.12 & 0.38 & 0.01 & 0.11 & 0.04 \\
\hline 118 & 0.01 & 0.45 & 0.01 & 0.33 & 0.25 & 0.52 \\
\hline 120 & 0.48 & 0.49 & 0.99 & 0.40 & 0.48 & 0.44 \\
\hline 122 & 0.10 & 0.02 & 0.06 & 0.20 & 0.05 & 0.15 \\
\hline 124 & 0.63 & 1.78 & $3.57 *$ & 0.24 & 0.85 & 0.73 \\
\hline 126 & 1.11 & 2.08 & 0.36 & 0.21 & 1.39 & 1.65 \\
\hline 128 & 1.07 & $3.08 *$ & 2.50 & 0.38 & 0.31 & 0.01 \\
\hline 130 & 0.67 & 0.40 & 0.06 & 0.50 & 0.17 & 0.33 \\
\hline 132 & 2.70 & $2.76^{*}$ & $3.21^{*}$ & $6.09 * *$ & $5.43 * *$ & $3.32 *$ \\
\hline 134 & 0.05 & 0.89 & 0.61 & & & \\
\hline \multicolumn{7}{|c|}{ Association tests within family } \\
\hline 116 & 0.35 & 0.10 & 0.47 & - & - & - \\
\hline 118 & 0.03 & 0.78 & 0.00 & 0.03 & 0.01 & 0.07 \\
\hline 120 & 1.92 & $3.58 * *$ & $3.69 * *$ & 0.06 & 0.19 & 0.80 \\
\hline 122 & 0.77 & 1.96 & 1.85 & 0.78 & 0.51 & 0.29 \\
\hline 124 & - & - & - & - & - & - \\
\hline 126 & 1.24 & $3.31 *$ & 1.13 & 0.31 & 0.18 & 0.04 \\
\hline 128 & $3.51 *$ & $6.35^{* * * *}$ & $6.23 * * *$ & - & - & - \\
\hline 130 & 1.87 & 0.39 & 0.13 & - & - & - \\
\hline 132 & - & - & - & - & - & - \\
\hline 134 & - & - & - & & & \\
\hline \multicolumn{7}{|c|}{ Multi-allelic association tests } \\
\hline \multirow{2}{*}{ Linkage tests } & 5.15 & $8.46^{*}$ & 5.61 & 0.89 & 0.78 & 0.96 \\
\hline & 0.34 & 0.94 & 0.15 & $7.30 * * *$ & $8.93 * * *$ & $5.94 * *$ \\
\hline
\end{tabular}

stratification caused by population association (Rabinowitz 1997; Fulker et al. 1999; Abecasis et al. 2000a, 2000b). On the other hand, linkage and association are two distinct and complementary methods for gene detection. Allowing for the presence of linkage disequilibrium may increase the linkage information provided by the sample pedigree, and vice versa. Therefore, both types of tests should be conducted on the same complete set of all available data (Terwilliger and Göring 2000). In this study, we have tested linkage and association between the CA repeat polymorphism of the IL6 gene and BMD, BMI, fat mass, PFM using the QTDT in two large independent samples with different study designs. We found weak evidence for linkage with spine BMD and for association with hip BMD in the sample of multigenerational pedigrees. For BMI, fat mass, and PFM, highly significant $(P<0.01)$ or significant $(P<0.05)$ results were observed for linkage in the samples of nuclear families and for association in the multigenerational pedigrees. By testing for association and linkage, our results provide strong evidence that genetic variation in or near the IL6 locus is involved in the etiology of obesity and weak evidence for osteoporosis.
IL6 is involved in a variety of metabolic processes, including glucose and lipid metablism (Mohamed-Ali et al. 1998), down-regulation of adipocyte lipoprotein lipase in mice (Greenberg et al. 1992) and stimulation of acute protein synthesis (Papanicolaou et al. 1998). One third of circulating IL6 levels has been estimated to originate from adipose tissue (Mohamed-Ali et al. 1997; Xing et al. 1997). The role of the IL6 gene in the etiology of obesity is controversial. Circulating IL6 levels have been reported to be elevated in obese people, and correlated with BMI (Vgontzas et al. 1997). The IL6 $-174 \mathrm{G} / \mathrm{C}$ polymorphism is associated with some indices of body composition and parameters of glucose and insulin homeostasis in French-Canadian men (Berthier et al. 2003). Chromosome 7p15-22 showed some evidence of linkage to obesity-related phenotypes in several genomescan linkage studies (Hager et al. 1998; Wu et al. 2002; Deng et al. 2002a). However, IL6-deficient mice develop mature-onset obesity (Wallenius et al. 2002). In this study, significant results were found for both linkage and association for BMI, fat mass and PFM. Given the propensity for association studies to produce false positive or false negative results, the findings from the 
Table $3 \chi^{2}$ statistics obtained from QTDT analysis of the IL6 gene and BMD. A blank entry indicates lack of the allele in the sample; a dash indicates not tested because the frequency of the allele is less than $5 \%$; asterisks indicate significant values

\footnotetext{
* Significant at the level of 0.10 **Significant at the level of 0.05 $* * *$ Significant at the level of
} 0.01

\begin{tabular}{|c|c|c|c|c|}
\hline \multirow[t]{2}{*}{ IL6 alleles (bp) } & \multicolumn{2}{|c|}{ Multigenerational pedigrees } & \multicolumn{2}{|c|}{ Nuclear families } \\
\hline & Spine BMD & Hip BMD & Spine BMD & Hip BMD \\
\hline \multicolumn{5}{|c|}{ Tests of population stratification } \\
\hline 116 & 1.41 & 0.56 & - & - \\
\hline 118 & 0.21 & 0.00 & $2.99 *$ & 1.55 \\
\hline 120 & 0.00 & 1.57 & 0.50 & 0.49 \\
\hline 122 & 0.00 & $2.78 *$ & 0.74 & 1.49 \\
\hline 124 & - & - & - & - \\
\hline 126 & 0.13 & 0.30 & 0.20 & 1.89 \\
\hline 128 & 0.18 & 1.66 & - & - \\
\hline 130 & 0.73 & 0.18 & - & - \\
\hline 132 & - & - & - & - \\
\hline 134 & - & - & & \\
\hline \multicolumn{5}{|c|}{ Total association tests } \\
\hline 116 & 0.22 & 0.93 & 0.05 & 0.09 \\
\hline 118 & 0.22 & 0.70 & 1.69 & 0.75 \\
\hline 120 & 0.19 & 1.91 & 2.18 & 0.92 \\
\hline 122 & 0.03 & 0.21 & 0.43 & 1.59 \\
\hline 124 & $3.66^{*}$ & 1.22 & 0.15 & 1.54 \\
\hline 126 & 0.06 & 0.00 & 0.85 & 0.40 \\
\hline 128 & 0.03 & 1.32 & 0.22 & 1.09 \\
\hline 130 & 0.02 & 0.55 & $12.05^{* * *}$ & $3.82 * *$ \\
\hline 132 & 0.12 & 0.00 & 0.02 & $2.76^{*}$ \\
\hline 134 & 0.02 & 0.93 & & \\
\hline \multicolumn{5}{|c|}{ Association tests within family } \\
\hline 116 & 0.07 & 0.23 & - & - \\
\hline 118 & 0.00 & 0.42 & 0.34 & 0.24 \\
\hline 120 & 0.08 & $3.48 *$ & 2.15 & 1.30 \\
\hline 122 & 0.01 & 1.9 & 1.17 & $3.01 *$ \\
\hline 124 & - & - & - & - \\
\hline 126 & 0.01 & 0.15 & 0.04 & 0.55 \\
\hline 128 & 0.17 & $2.92 *$ & - & - \\
\hline 130 & 0.47 & 0.08 & - & - \\
\hline 132 & - & - & - & - \\
\hline 134 & - & - & & \\
\hline \multicolumn{5}{|c|}{ Multi-allelic association tests } \\
\hline \multirow{2}{*}{ Linkage tests } & 0.41 & 4.91 & 2.73 & 3.61 \\
\hline & $3.30^{*}$ & 1.58 & 0.91 & 0.18 \\
\hline
\end{tabular}

initial study should be replicated using an independent sample (Cooper et al. 2002). Although we found a significant result of linkage of the CA repeat polymorphism of the IL6 gene with BMI, fat mass, and PFM in the sample of nuclear families, this finding is not replicated in the sample of 79 multigenerational pedigrees. Failure of replication of the study may be due to different sets of genes operating in different populations or a false positive result (Rao 2001). Similarly, we found significant association between the CA repeat polymorphism of the IL6 gene and fat mass and PFM in 79 multigenerational pedigrees in the association tests within family. However, in the sample of nuclear families, results of association tests within the family were not significant, presumably reflecting the lack of linkage disequilibrium between the polymorphism and the functional variation in this population. The extent of linkage disequilibrium varies widely across the populations (Pritchard and Przeworski 2001). Notably, significant population stratification was detected for the 11-repeat and 15repeat alleles in the sample of the multigenerational pedigrees (Table 2). Interestingly, total association tests for these two alleles were not significant, whereas significant results were detected for fat mass and PFM at the 15-repeat allele $(128 \mathrm{bp})(P<0.01)$ and 11 -repeat allele $(120 \mathrm{bp})(P<0.05)$ when testing for association within family. These results highlighted the advantage and robustness of the TDT test. To our knowledge, few studies have examined the relationship between polymorphisms of the IL6 gene and obesity-related phenotypes (Rankinen et al. 2002; Berthier et al. 2003). Therefore, our results may be regarded as provisional, and further validation studies in other populations need to be pursued (Cooper et al. 2002).

Murray et al. (1997) reported a significant relationship between BMD and a variable number tandem repeat (VNTR) polymorphism in the $3^{\prime}$ flank of the IL6 gene among women living in the northeast of Scotland. However, Takacs et al. (2000) found no evidence for either linkage or association between the VNTR polymorphism of the IL6 gene locus and BMD of the spine or hip in either Caucasians or African Americans. Tsukamoto et al. (1999) and Ota et al. (1999) described association of the CA repeat polymorphism of the ILG 
gene with radial BMD, as well as genetic linkage of the IL6 locus to human osteopenia, by means of sib-pair analysis. Subsequently, they identified three singlenucleotide polymorphisms within the $5^{\prime}$ regulatory region of the IL6 gene in a Japanese population sample, and found a significant correlation, in 470 subjects, between the presence of the $\mathrm{G}$ allele at the nucleotide -634 in the promoter region of the IL6 gene and decreased BMD (Ota et al. 2001). Moreover, Ferrari et al. (2001) found that a functional $\mathrm{G} \rightarrow \mathrm{C}$ polymorphism at position -174 in the IL6 gene promoter was associated with low bone resorption and less decrease in bone mass in postmenopausal women. In addition, the IL6 gene locus showed weak linkage with BMD of the lumbar spine but not of the femoral neck in Caucasian families in the UK (Duncan et al. 1999). In this study, we found weak evidence of linkage with spine BMD $(P=0.069)$ and association with hip BMD in the sample of the extended multigenerational pedigrees, which was consistent with our previous whole genome screen results, where $7 \mathrm{p} 22$ showed some evidence of linkage to spine BMD with a multi-point $\mathrm{LOD}=1.93$ (Deng et al. 2002b). On the other hand, linkage analyses in the QTDT are based on the identity-by-descent (IBD) of sibpairs. Only $100 \mathrm{nu}-$ clear families with more than one child in our nuclear families are involved in linkage analyses, so the power of the linkage test in nuclear families is limited. Our results support the hypothesis that the IL6 locus is involved as a determinant of BMD, although the ILG locus is unlikely to play a major role in the pathogenesis of osteoporosis.

A positive association between BMI and BMD has been documented in a number of studies (Felson et al. 1993; Ravn et al. 1999; Ertungealp et al. 1999; Nguyen et al. 2000). Some studies have employed BMI to adjust BMD (Bendavid et al. 1996). In the present study, we have demonstrated that the CA repeat polymorphism of the IL6 gene is related to BMD and obesityrelated phenotypes. Therefore, the IL6 gene may be a shared genetic locus for BMI and BMD. Future studies may focus on identification of functional mutation(s) and elucidation of the mechanism of the association.

Acknowledgements Investigators of this work are partially supported by grants from Health Future Foundation, NIH grants (K01 AR02170-01, R01 AR45349-01, R01 GM60402-01A1, P01 DC01813-07), grants from State of Nebraska Cancer and Smoking Related Disease Research Program, US Department of Energy grant DE-FG03-00ER63000/A00, Creighton University, grants (30025025, 30170504, 30230210) from National Science Foundation of China, a Seed Fund (25000106) and a key grant from the Ministry of Education of P.R. China, and a grant (25000612) from HuNan Normal University. We acknowledge the generous cooperation of participating families. Support from all members in Dr. Deng's lab is greatly appreciated.

Appendix The basic characteristics of 1,816 subjects from 79 multigenerational pedigrees are listed in table A below. The data for each entry in columns 3-11 are: the mean, SD (in parentheses), and the sample size [in brackets]. For each age strata, $M$ and $F$ indicate data from males and females, respectively

\begin{tabular}{|c|c|c|c|c|c|c|c|c|c|c|}
\hline $\begin{array}{l}\text { Age groups } \\
\text { (years) }\end{array}$ & Sex & $\begin{array}{l}\text { Ages } \\
\text { (years) }\end{array}$ & $\begin{array}{l}\text { Height } \\
(\mathrm{m})\end{array}$ & $\begin{array}{l}\text { Weight } \\
(\mathrm{kg})\end{array}$ & $\begin{array}{l}\text { Spine BMD } \\
\left(\mathrm{g} / \mathrm{m}^{2}\right)\end{array}$ & $\underset{\left(\mathrm{g} / \mathrm{m}^{2}\right)}{\mathrm{Hip}}$ & $\begin{array}{l}\mathrm{BMI} \\
\left(\mathrm{kg} / \mathrm{m}^{2}\right)\end{array}$ & $\begin{array}{l}\text { Fat mass } \\
(\mathrm{kg})\end{array}$ & $\begin{array}{l}\text { Lean mass } \\
(\mathrm{kg})\end{array}$ & PFM (\%) \\
\hline \multirow[t]{2}{*}{ 20-29.99 } & M & $\begin{array}{l}25.0(2.8) \\
{[85]}\end{array}$ & $\begin{array}{l}1.81(0.07) \\
{[84]}\end{array}$ & $\begin{array}{l}85.8(15.7) \\
{[83]}\end{array}$ & $\begin{array}{l}1.10(0.13) \\
{[85]}\end{array}$ & $\begin{array}{l}1.10(0.15) \\
{[85]}\end{array}$ & $\begin{array}{l}26.2(4.5) \\
{[83]}\end{array}$ & $\begin{array}{l}18.7(9.4) \\
{[82]}\end{array}$ & $\begin{array}{l}66.5(9.2) \\
{[82]}\end{array}$ & $\begin{array}{l}21.0(7.1) \\
{[82]}\end{array}$ \\
\hline & F & $\begin{array}{l}25.6(2.9) \\
{[126]}\end{array}$ & $\begin{array}{l}1.66(0.06) \\
{[126]}\end{array}$ & $\begin{array}{l}66.9(13.5) \\
{[126]}\end{array}$ & $\begin{array}{l}1.06(0.18) \\
{[125]}\end{array}$ & $\begin{array}{l}0.97(0.13) \\
{[126]}\end{array}$ & $\begin{array}{l}24.3(5.0) \\
{[126]}\end{array}$ & $\begin{array}{l}22.0(8.5) \\
{[121]}\end{array}$ & $\begin{array}{l}44.5(5.8) \\
{[121]}\end{array}$ & $\begin{array}{l}32.2(7.2) \\
{[121]}\end{array}$ \\
\hline \multirow[t]{2}{*}{$30-39.99$} & M & $\begin{array}{l}35.5(2.8) \\
{[137]}\end{array}$ & $\begin{array}{l}1.79(0.07) \\
{[134]}\end{array}$ & $\begin{array}{l}89.0(14.3) \\
{[134]}\end{array}$ & $\begin{array}{l}1.08(0.13) \\
{[137]}\end{array}$ & $\begin{array}{l}1.06(0.13) \\
{[137]}\end{array}$ & $\begin{array}{l}27.6(4.0) \\
{[134]}\end{array}$ & $\begin{array}{l}21.3(8.2) \\
{[127\}}\end{array}$ & $\begin{array}{l}67.3(8.2) \\
{[127]}\end{array}$ & $\begin{array}{l}23.4(6.1) \\
{[127]}\end{array}$ \\
\hline & $\mathrm{F}$ & $\begin{array}{l}35.8(2.7) \\
{[210]}\end{array}$ & $\begin{array}{l}1.67(0.07) \\
{[210]}\end{array}$ & $\begin{array}{l}70.7(14.4) \\
{[208]}\end{array}$ & $\begin{array}{l}1.07(0.13) \\
{[210]}\end{array}$ & $\begin{array}{l}0.97(0.14) \\
{[210]}\end{array}$ & $\begin{array}{l}25.5(5.1) \\
{[208]}\end{array}$ & $\begin{array}{l}24.8(9.7) \\
{[201]}\end{array}$ & $\begin{array}{l}46.2(6.6) \\
{[201]}\end{array}$ & $\begin{array}{l}33.9(7.4) \\
{[201]}\end{array}$ \\
\hline \multirow[t]{2}{*}{$40-49.99$} & M & $\begin{array}{l}45.1(2.9) \\
{[184]}\end{array}$ & $\begin{array}{l}1.79(0.07) \\
{[182]}\end{array}$ & $\begin{array}{l}90.3(13.5) \\
{[182]}\end{array}$ & $\begin{array}{l}1.08(0.15) \\
{[184]}\end{array}$ & $1.06(0.15)$ & $\begin{array}{l}28.2(3.8) \\
{[182]}\end{array}$ & $\begin{array}{l}22.9(7.3) \\
{[176]}\end{array}$ & $\begin{array}{l}67.3(8.0) \\
{[176]}\end{array}$ & $\begin{array}{l}24.9(5.2) \\
{[176]}\end{array}$ \\
\hline & $\mathrm{F}$ & $\begin{array}{l}44.7(2.9) \\
{[222]}\end{array}$ & $\begin{array}{l}1.65(0.06) \\
{[222]}\end{array}$ & $\begin{array}{l}72.7(16.1) \\
{[222]}\end{array}$ & $\begin{array}{l}1.05(0.14) \\
{[222]}\end{array}$ & $\begin{array}{l}0.94(0.14) \\
{[220]}\end{array}$ & $\begin{array}{l}26.8(5.5) \\
{[221]}\end{array}$ & $\begin{array}{l}26.6(10.1) \\
{[210]}\end{array}$ & $\begin{array}{l}45.6(6.7) \\
{[210]}\end{array}$ & $\begin{array}{l}35.8(6.8) \\
{[210]}\end{array}$ \\
\hline \multirow[t]{2}{*}{ 50-59.99 } & M & $\begin{array}{l}54.2(3.0) \\
{[102]}\end{array}$ & $\begin{array}{l}1.77(0.11) \\
{[102]}\end{array}$ & $\begin{array}{l}90.7(13.4) \\
{[102]}\end{array}$ & $\begin{array}{l}1.09(0.15) \\
{[102]}\end{array}$ & $\begin{array}{l}1.04(0.13) \\
{[102]}\end{array}$ & $\begin{array}{l}28.8(4.0) \\
{[101]}\end{array}$ & $\begin{array}{l}24.2(7.5) \\
{[99]}\end{array}$ & $\begin{array}{l}66.5(8.2) \\
{[99]}\end{array}$ & $\begin{array}{l}26.3(5.1) \\
{[99]}\end{array}$ \\
\hline & $\mathrm{F}$ & $\begin{array}{l}54.2(3.1) \\
{[120]}\end{array}$ & $\begin{array}{l}1.64(0.05) \\
{[120]}\end{array}$ & $\begin{array}{l}76.2(15.9) \\
{[120]}\end{array}$ & $\begin{array}{l}1.01(0.15) \\
{[120]}\end{array}$ & $\begin{array}{l}0.94(0.14) \\
{[120]}\end{array}$ & $\begin{array}{l}28.4(5.5) \\
{[120]}\end{array}$ & $\begin{array}{l}30.1(9.9) \\
{[115]}\end{array}$ & $\begin{array}{l}46.3(6.7) \\
{[115]}\end{array}$ & $\begin{array}{l}38.5(6.0) \\
{[115]}\end{array}$ \\
\hline \multirow[t]{2}{*}{ 60-69.99 } & M & $\begin{array}{l}65.0(2.8) \\
{[52]}\end{array}$ & $\begin{array}{l}1.77(0.07) \\
{[52]}\end{array}$ & $\begin{array}{l}90.6(14.9) \\
{[52]}\end{array}$ & $\begin{array}{l}1.09(0.20) \\
{[51]}\end{array}$ & $\begin{array}{l}1.00(0.15) \\
{[52]}\end{array}$ & $\begin{array}{l}29.0(4.4) \\
{[52]}\end{array}$ & $\begin{array}{l}23.9(7.4) \\
{[50]}\end{array}$ & $\begin{array}{l}66.1(8.3) \\
{[50]}\end{array}$ & $\begin{array}{l}26.0(4.9) \\
{[50]}\end{array}$ \\
\hline & $\mathrm{F}$ & $\begin{array}{l}64.9(3.0) \\
{[87]}\end{array}$ & $\begin{array}{l}1.62(0.06) \\
{[87]}\end{array}$ & $\begin{array}{l}77.4(17.4) \\
{[85]}\end{array}$ & $\begin{array}{l}0.96(0.19) \\
{[87]}\end{array}$ & $\begin{array}{l}0.88(0.17) \\
{[86]}\end{array}$ & $\begin{array}{l}29.3(6.4) \\
{[85]}\end{array}$ & $\begin{array}{l}31.5(10.8) \\
{[79]}\end{array}$ & $\begin{array}{l}46.0(7.7) \\
{[79]}\end{array}$ & $\begin{array}{l}39.7(6.4) \\
{[79]}\end{array}$ \\
\hline \multirow[t]{2}{*}{ 70-79.99 } & M & $\begin{array}{l}74.1(2.7) \\
{[53]}\end{array}$ & $\begin{array}{l}1.74(0.06) \\
{[53]}\end{array}$ & $\begin{array}{l}87.3(12.5) \\
{[53]}\end{array}$ & $\begin{array}{l}1.14(0.22) \\
{[53]}\end{array}$ & $\begin{array}{l}1.00(0.14) \\
{[53]}\end{array}$ & $\begin{array}{l}28.7(4.0) \\
{[53]}\end{array}$ & $\begin{array}{l}24.8(7.9) \\
{[52]}\end{array}$ & $\begin{array}{l}61.6(6.5) \\
{[52]}\end{array}$ & $\begin{array}{l}28.2(5.7) \\
{[52]}\end{array}$ \\
\hline & $\mathrm{F}$ & $\begin{array}{l}74.3(2.9) \\
{[54]}\end{array}$ & $\begin{array}{l}1.60(0.06) \\
{[54]}\end{array}$ & $\begin{array}{l}74.9(13.6) \\
{[51]}\end{array}$ & $\begin{array}{l}0.96(0.21) \\
{[54]}\end{array}$ & $\begin{array}{l}0.86(0.17) \\
{[54]}\end{array}$ & $\begin{array}{l}29.0(5.4) \\
{[51]}\end{array}$ & $\begin{array}{l}29.9(8.6) \\
{[52]}\end{array}$ & $\begin{array}{l}44.4(5.7) \\
{[52]}\end{array}$ & $\begin{array}{l}39.6(5.2) \\
{[52]}\end{array}$ \\
\hline \multirow[t]{2}{*}{ 80-89.99 } & M & $83.1(2.5)$ & $1.71(0.08)$ & $83.6(11.8)$ & $1.14(0.25)$ & $0.92(0.10)$ & $28.5(3.6)$ & $23.6(4.8)$ & $\begin{array}{l}59.7(7.4) \\
{[137}\end{array}$ & $28.2(3.5)$ \\
\hline & $\mathrm{F}$ & $\begin{array}{l}83.1(2.5) \\
{[18]}\end{array}$ & $\begin{array}{l}1.56(0.07) \\
{[18]}\end{array}$ & $\begin{array}{l}73.3(15.3) \\
{[18]}\end{array}$ & $\begin{array}{l}1.03(0.22) \\
{[18]}\end{array}$ & $\begin{array}{l}0.79(0.13) \\
{[17]}\end{array}$ & $\begin{array}{l}30.3(6.2) \\
{[18]}\end{array}$ & $\begin{array}{l}30.0(9.7) \\
{[18]}\end{array}$ & $\begin{array}{l}43.1(5.9) \\
{[18]}\end{array}$ & $\begin{array}{l}39.9(6.2) \\
{[18]}\end{array}$ \\
\hline
\end{tabular}


The basic characteristics of 636 subjects from 157 nuclear families are listed in table B below. The data for each entry in columns 3-11 are: the mean, SD (in parentheses), and the sample size [in brackets]. For each age strata, $M$ and $F$ indicate data from males and females, respectively

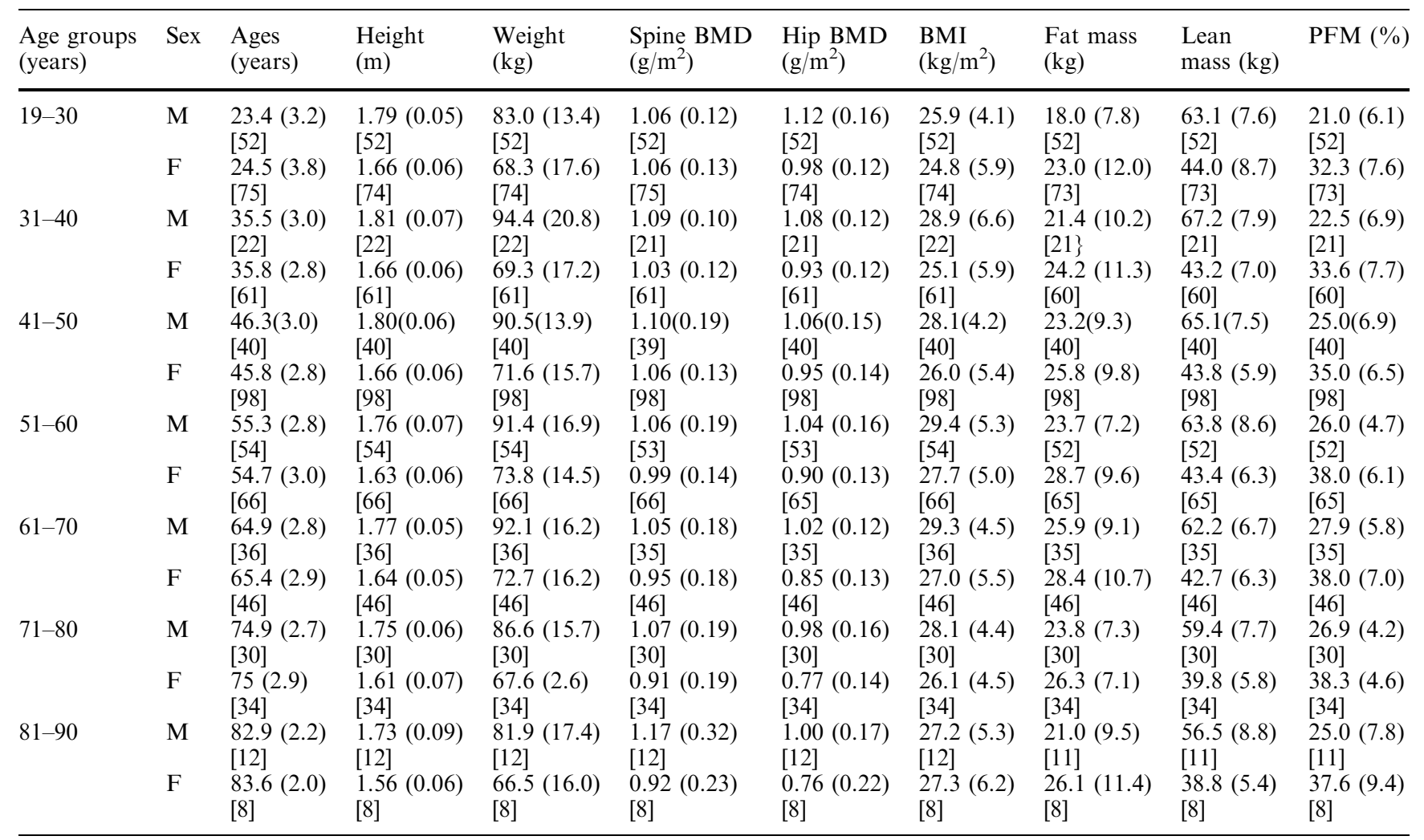

\section{References}

Abecasis GR, Cardon LR, Cookson WO (2000a) A general test of association for quantitative traits in nuclear families. Am $\mathbf{J}$ Hum Genet 66:279-292

Abecasis GR, Cookson WO, Cardon LR (2000b) Pedigree tests of transmission disequilibirum. Eur J Hum Genet 8:545-551

Audí L, Carcía-Ramírez M, Carrascosa A (1999) Genetic determinants of bone mass. Horm Res 51:105-123

Bendavid EJ, Shan J, Barrett-Connor E (1996) Factors associated with bone mineral density in middle-aged men. $\mathrm{J}$ Bone Miner Res 11:1185-1190

Berthier MT, Paradis AM, Tchernof A, Bergeron J, Prud'homme D, Despres JP, Vohl MC (2003) The interleukin $6-174 \mathrm{G} / \mathrm{C}$ polymorphism is associated with indices of obesity in men. J Hum Genet 48:14-19

Borecki IB, Higgins M, Schreiner PJ, Arnett DK, Mayer Davis E, Hunt SC, Province MA (1998) Evidence for multiple determinants of the body mass index: the National Heart, Lung, and Blood Institute Family Heart Study. Obes Res 6:107-114

Cooper DN, Nussbaum RL, Krawezak M (2002) Proposed guidelines for papers describing DNA polymorphism-disease associations. Hum Genet 110:207-208

Deng HW (2001) Population admixture may appear to mask, change or reverse genetic effects of genes underlying complex traits. Genetics 159:1319-1323

Deng HW, Stegman MR, Davies M, Conway T, Recker RR (1999) Genetic determination of peak bone mass (PBM) at hip and spine and common familiar environmental effects on bone qualities. J Clin Densitom 2:251-263

Deng HW, Chen WM, Conway T, Zhou Y, Davies KM, Stegman MR, Deng HY, Recker RR (2000) Determination of bone mineral density of the hip and spine in human pedigrees by genetic and life-style factors. Genet Epidemiol 19:160-177
Deng HW, Lai DB, Li J, Conway T, Li J, Xu FH, Davies KM, Recker RR (2001) Characterization of genetic and life-style factors for determining variation of BMI, fat mass, percentage fat mass, and lean mass. J Clin Densitom 4:353-362

Deng HW, Deng HY, Liu YJ, Liu YZ, Xu FH, Shen H, Conway T, Li JL, Huang QY, Davies KM, Recker RR (2002a) A genomewide linkage scan for quantitative trait loci for obesity phenotypes. Am J Hum Genet 70:1138-1151

Deng HW, Xu FH, Huang QY, Shen H, Deng HY, Conway T, Liu YJ, Liu YZ, Li JL, Zhang HT, Davies KM, Recker RR (2002b) A whole-genome linkage scan suggests several genomic regions potentially containing quantitative trait loci for Osteoporosis. J Clin Endocrinol Metab 87:5151-5159

Dequeker J, Nijs J, Verstraeten A, Geusens P, Gevers G (1987) Genetic determinants of bone mineral content at the spine and radius: A twin study. Bone 8:207-209

Duncan EL, Brown MA, Sinsheimer J, Bell J, Carr AJ, Wordsworth BP, Wass JAH (1999) Suggestive linkage of the parathyroid receptor type 1 to osteoporosis. J Bone Miner Res 14:1993-1999

Ertungealp E, Seyisoglu H, Erel CT, Senturk LM, Gezer A (1999) Changes in bone mineral density with age, menopausal status and body mass index in Turkish women. Climacteric 2:45-51

Felson DT, Zhang Y, Hannan MT, Anderson JA (1993) Effects of weight and body mass index on bone mineral density in men and women: the Framingham study. J Bone Miner Res 8:567573

Ferrari SL, Garnero P, Emond S, Montgomery H, Humphries SE, Greenspan SL (2001) A functional polymorphic variant in the interleukin-6 gene promoter associated with low bone resorption in postmenopausal women. Arthritis Rheum 44:196201

Fulker DW, Cherny SS, Sham PC, Hewitt JK (1999) Combined linkage and association sib-pair analysis for quantitative traits. Am J Hum Genet 64:259-267 
Greenberg AS, Nordan RP, McIntosh M, Calvo JC, Scow RO, Jablons D (1992) Interleukin 6 reduces lipoprotein lipase activity in adipose tissue of mice in vivo and in 3T3-L1 adipocytes: a possible role for interleukin 6 in cancer cachexia. Cancer Res 52:4113-4116

Gueguen R, Jouanny P, Guillemin F, Kuntz C, Pourel J, Siest G (1995) Segregation analysis and variance components analysis of bone mineral density in health families. J Bone Miner Res 10:2017-2022

Hager J, Dina C, Francke S, Dubois S, Houari M, Vatin V, Vaillant E, Lorentz N, Basdevant A, Clement K, Guy-Grand B, Froguel P (1998) A genome-wide scan for human obesity genes reveals a major susceptibility locus on chromosome 10 . Nat Genet 20:304-308

Huang QY, Recker RR, Deng HW (2003) Searching for osteoporosis genes in the post-genome era: progress and challenges. Osteoporos Int (in press)

Jilka RL, Hangoc G, Girasole G, Passeri G, Williams JS, Abrams B, Boyce B, Broxmeyer H, Manolagas SC (1992) Increased osteoclast development after estrogen loss: mediated by interleukin-6. Science 257:88-91

Kopelman PG (2000) Obesity as a medical problem. Nature 404:635-643

Melton LJ III, Chrischilles EA, Cooper C, Lane AW, Riggs BL (1992) Perspective: how many women have osteoporosis? J Bone Miner Res 7:1005-1010

Mohamed-Ali V, Goodrick S, Rawesh A, Katz DR, Miles JM, Yudkin JS, Klein S, Coppack SW (1997) Subcutaneous adipose tissue releases interleukin-6, but not tumor necrosis factoralpha, in vivo. J Clin Endocrinol Metab 82:4196-4200

Mohamed-Ali V, Pinkney JK, Coppack SW (1998) Adipose tissue as an endocrine and paracrine organ. Int J Obes Relat Metab Disord 22:1145-1158

Morrison NA, Qi JC, Tokita A, Kelly PJ, Crofts L, Nguyen TV, Sambrook PN, Eisman JA (1994) Prediction of bone density from vitamin D receptor alleles. Nature 367:284-287

Murray RE, McGuigan F, Grant SFA, Reid DM, Ralson SH (1997) Polymorphisms of the interleukin-6 gene are associated with bone mineral density. Bone 21:89-92

Nguyen TV, Howard GM, Kelly PJ, Eisman JA (1998) Bone mass, lean mass, and fat mass: same genes or same environments? Am J Epidemiol 147:3-16

Nguyen TV, Center JR, Eisman JA (2000) Osteoporosis in elderly men and women: effects of dietary calcium, physical activity, and body mass index. J Bone Miner Res 15: 322-331

O'Connell JR, Weeks DE (1998) PedCheck: A program for identification of genotype incompatibilities in linkage analysis. Am J Hum Genet 63:259-266

Ota N, Hunt SC, Nakajima T, Suzuki T, Hosoi T, Orimo H, Shirai Y, Emi M (1999) Linkage of interleukin 6 locus to human osteopenia by sibling pair analysis. Hum Genet 105:253-257

Ota N, Nakajima T, Nakazawa I, Suzuki T, Hosoi T, Orimo H, Inoue S, Shirai Y, Emi M (2001) A nucleotide variant in the promoter region of the interleukin- 6 gene associated with decreased bone mineral density. J Hum Genet 46:267-272

Papanicolaou DA, Wilder RL, Manolagas SC, Chrousos GP (1998) The pathophysiologic roles of interleukin-6 in human disease. Ann Intern Med 128:127-137

Pocock NA, Eisman JA, Hopper JL, Yeates MG, Sambrook PN, Ebert S (1987) Genetic determinants of bone mass in adults: a twin study. J Clin Invest 80:706-710

Pritchard JK, Przeworski M (2001) Linkage disequilibrium in human: models and data. Am J Hum Genet 69:1-14

Rabinowitz D (1997) A transmission disequilibrium test for quantitative trait loci. Hum Hered 47:342-350
Ralson SH (1994) Analysis of gene expression in human bone biopsies by polymerase chain reaction: evidence for enhanced cytokine expression in postmenopausal osteoporosis. J Bone Miner Res 9:883-890

Ralson SH (2002) Genetic determinants of bone mass and osteoporotic fracture. In: Bilezikian JP, Raisz LG, Rodan GA (eds.). Principles of bone biology, vol 2, 2nd edn. Academic Press, New York, NY, USA, pp 1259-1274

Rankinen T, Perusse L, Weisnagel SJ, Snyder EE, Chagnon YC, Bouchard C (2002) The human obesity gene map: the 2001 update. Obesity Res 10:196-243

Rao DC (2001) Genetic dissection of complex traits: an overview. Adv Genet 42:13-34

Ravn P, Cizza G, Bjarnason NH, Thompson D, Daley M, Wasnich RD, McClung M, Hosking D, Yates AJ, Christiansen C (1999) Low body mass index is an important risk factor for low bone mass and increased bone loss in early postmenopausal women: Early Postmenopausal Intervention Cohort (EPIC) study group. J Bone Miner Res 14:1622-1627

Recker RR, Lappe J, Davies K, Heaney K (2000) Characterization of perimenopausal bone loss: a perspective study. J Bone Miner Res 16:1965-1973

Rice T, Perusse L, Bouchard C, Rao DC (1999) Familial aggregation of body mass index and subcutaneous fat measures in the longitudinal Quebec family study. Genet Epidemiol 16:316-334

Rizzoli R, Bonjour JP, Ferrari SL (2001) Osteoporosis, genetics and hormones. J Mol Endocrinol 26:79-94

Roodman GD (1992) Interleukin-6: an osteotropic factor? J Bone Miner Res 7:475-476

Slemeda SW, Christian JCC, Williams CJ, Norton JA, Johnston CC (1991) Genetic determinants of bone mass in adult woman: A reevaluation of the twin model and the potential importance of gene interaction on heritability estimates. J Bone Miner Res 6:561-567

Takacs I, Koller DL, Peacock M, Christian JC, Evans WE, Hui SL, Conneally PM, Johnston CC, Foroud T, Econs MJ (2000) $\mathrm{Sib}$ pair linkage and association studies between bone mineral density and the interleukin-6 gene locus. Bone 27:169-173

Terwilliger JD, Göring HHH (2000) Gene mapping in the 20th and 21st centuries: statistical methods, data analysis, and experimental design. Hum Biol 72:63-132

Tsukamoto K, Yoshida H, Watanabe S, Suzuki T, Miyao M, Hosoi T, Orimo H, Emi M (1999) Association of radial bone mineral density with CA repeat polymorphism at the interleukin 6 locus in postmenopausal Japanese women. J Hum Genet 44:148-151

Vgontzas AN, Papanicolaou DA, Bixler EO, Kales A, Tyson K, Chrousos GP (1997) Elevation of plasma cytokines in disorders of excessive daytime sleepiness: role of sleep disturbance and obesity. J Clin Endocrinol Metab 82:1313-1316

Wallenius V, Wallenius K, Ahren B, Rudling M, Carlsten H, Dickson SL, Ohlsson C, Jansson J (2002) Interleukin-6-deficient mice develop mature-onset obesity. Nat Med 8:75-79

Weerakulwattana L, Tirawanchai N, Bunyaratavej N (2001) Analysis of polymorphism of the interleukin- 6 gene in Thai subjects with osteoporosis. J Med Assoc Thai 84 Suppl 2:S547-52

Wu X, Cooper RS, Borecki I, Hanis C, Bray M, Lewis CE, Zhu X, Kan D, Luke A, Curb D (2002) A combined analysis of genomewide linkage scans for body mass index, from the National Heart, Lung, and Blood Pressure Program. Am J Hum Genet 70:1247-1256

Xing H, Northrop JP, Grove JR, Kilpatrick KE, Su JL, Ringold GM (1997) TNF alpha-mediated inhibition and reversal of adipocyte differentiation is accompanied by suppressed expression of PPARgamma without effects on Pref-1 expression. Endocrinology 138:2776-2783 